\title{
Analisis SWOT Terhadap Kapabilitas BPBD Kota Padang dalam Pengurangan Risiko Bencana di Kota Padang
}

\author{
Eko Sammara Valentino Turnip ${ }^{1}$, Zikri Alhadi ${ }^{2}$ \\ 1,2 Universitas Negeri Padang \\ Email: ianunpzikri@yahoo.co.id
}

\begin{abstract}
Abstrak
Penelitian ini memiliki tujuan untuk mengetahui kekuatan, kelemahan, peluang, dan ancaman terhadap kapabilitas yang dimiliki oleh BPBD Kota Padang dalam pengurangan risiko bencana di Kota Padang. Metode penelitian yang dipakai pada penelitian ini ialah penelitian kualitatif dengan metode deskriptif. Data dikumpulkan lewat wawancara dengan informan, observasi di lapangan dan studi dokumentasi. Penelitian ini dilakukan di kantor BPBD Kota Padang. Dalam penelitian ini informan dipilih dengan memakai teknik purposive sampling dan snowball sampling. Hasil penelitian ini bertujuan untuk mengetahui kondisi dan permasalahan yang dialami BPBD Kota Padang pada kekuatan, kelemahan, peluang, dan ancaman yang dimiliki oleh BPBD Kota Padang dalam pengurangan risiko bencana di Kota Padang. Dari hasil analisis tersebut diharapkan BPBD Kota Padang dapat merumuskan strategi yang tepat sesuai dengan kondisi dan potensi yang ada di BPBD Kota Padang.

Kata Kunci: Analisis SWOT, Kapabilitas, Pengurangan Risiko Bencana
\end{abstract}

Abstract
This study aims to determine the strengths, weaknesses, opportunities, and threats to the capabilities possessed by the Padang City BPBD in disaster risk reduction in Padang City. The research method used in this study is qualitative research with descriptive methods. Data was collected through interviews with informants, field observations and documentation studies. This research was conducted at the BPBD office in Padang City. In this study, informants were selected using purposive sampling and snowball sampling techniques. The results of this study aim to determine the conditions and problems experienced by Padang City BPBD on the strengths, weaknesses, opportunities, and threats that the Padang BPBD has in disaster risk reduction in Padang City. From the results of the analysis, it is expected that the BPBD of Padang City can formulate the right strategy following the conditions and potential that exist in the BPBD of Padang City.

Keywords: SWOT Analysis, Capability, Disaster Risk Reduction

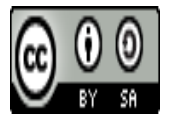

Received: July 25, 2019

Revised: July 30, 2019

Available Online: July 31, 2019

\section{Pendahuluan}

Jurnal Perspektif: Jurnal Kajian Sosiologi dan Pendidikan Vol. 2, No. 3, Th. 2019 ISSN. 2622-1748 
Pemerintah memiliki tanggung jawab dalam melakukan penanggulangan bencana sesuai yang telah diatur pada Undang-Undang No. 24 Tahun 2007 tentang Penanggulangan Bencana. Undang-undang tersebut menetapkan bahwa yang memiliki tanggung jawab dalam melakukan penanggulangan bencana ialah pemerintah pusat dan pemerintah daerah. Ditingkat pusat, penanggulangan bencana dilakukan oleh lembaga pemerintah nondepartemen yakni BNPB (Badan Nasional Penanggulangan Bencana) dan BPBD (Badan Penanggulangan Bencana Daerah) pada tingkat daerah.

Kota Padang merupakan wilayah yang memiliki potensi bencana yang paling tinggi bila dibandingkan dengan daerah-daerah lain di Provinsi Sumatera Barat. Maka dari itu perlu dipersiapkan penanganan bencana yang baik untuk menghadapi bencana yang sewaktu-waktu terjadi di Kota Padang. Untuk itu, pemerintah daerah membentuk BPBD yang berkoordinasi langsung dengan BNPB yang diharapkan dapat lebih cepat tanggap dan responsif terhadap kemungkinan terjadinya bencana alam. BPBD sebagai badan yang memiliki tugas dalam melakukan penanggulangan bencana memiliki kewajiban untuk mengkoordinasikan seluruh stakeholder dalam melakukan manajemen bencana.

Pada pelaksanaan tugas dan fungsinya di lapangan, BPBD Kota Padang masih sangat lemah dalam melakukan koordinasi dengan seluruh pemangku kepentingan yang memiliki andil dalam kebencanaan. Selain itu, dari segi sumber daya manusia yang dimiliki BPBD Kota Padang juga masih belum memenuhi secara kuantitas maupun kualitas. Selanjutnya permasalahan lain yang ada di BPBD Kota padang ialah minimnya anggaran yang dimiliki sehingga menghambat pelaksanaan program dan kegiatan BPBD Kota Padang. Disamping itu, pada aspek teknis khususnya sarana dan prasarana yang dimiliki BPBD Kota Padang juga masih kekurangan dari segi jumlah dan kelengkapan alat.

Untuk itu, perlu dilakukan analisis untuk melihat kekuatan, kelemahan, peluang dan ancaman yang dimiliki oleh BPBD Kota Padang sehingga dapat dirumuskan strategi yang tepat dalam menghadapi kondisi dan permasalahan yang terjadi. Menurut Salusu (2015:175) mengatakan bahwa kekuatan dan kelemahan merupakan faktor internal yang harus selalu dianalisis hubungannya dengan faktor eksternal, yaitu peluang dan ancaman. Kedua faktor internal dan eksternal tersebut harus bertemu pada titik singgung (the fit) dengan visi dan misi organisasi.

Sesuai dengan pendapat Kearns (1992) yang mengatakan apabila melihat suatu peluang dan organisasi memiliki kekuatan untuk menangkap peluang itu, maka organisasi akan lebih cepat berkembang. Sebaliknya, jika ada ancaman maka organisasi harus melakukan mobilisasi sumber daya untuk dapat melunakan ancaman itu. Jika organisasi melihat ada peluang sementara terdapat kelemahan pada organisasi tersebut maka organisasi tidak mempunyai kekuatan untuk menangkap peluang itu, maka posisi stratejik organisasi berada pada isu divestment/investment. Bisa dipilih, membiarkan peluang itu pergi (divestment) atau berusaha menambah kekuatan, melakukan investasi sehingga peluang itu dapat ditangkap (investment) yang akhirnya kelemahan dapat berubah menjadi kekuatan. Yang parah ialah jika ada ancaman, sementara organisasi punya kelemahan, maka posisi organisasi berada pada posisi strategi damage control. Oleh karena itu, artikel ini memiliki tujuan guna mengetahui bagaimana kekuatan, kelemahan, peluang, dan ancaman yang dimiliki oleh BPBD Kota Padang dalam pengurangan risiko bencana di Kota Padang.

\section{Metode Penelitian}

Dalam penelitian ini, peneliti menggunakan jenis penelitian kualitatif dengan metode menggunakan deskriptif. Moleong (2007:6) mengatakan bahwa penelitian kualitatif ialah 
penelitian yang bertujuan untuk memahami fenomena mengenai apa saja yang dialami oleh subjek penelitian secara holistik dan dengan cara deskripsi berbentuk kata-kata dan bahasa, pada suatu konteks khusus yang alamiah dan dengan memanfaatkan berbagai macam metode ilmiah. Penelitian ini dilakukan di Kantor BPBD Kota Padang. Dalam memilih informan, peneliti menggunakan teknik purposive sampling yaitu pemilihan informan yang dilakukan dengan sengaja dan teknik snowball sampling yakni pengambilan sampel sumber data yang pada awalnya berjumlah sedikit hingga semakin besar.

Pengumpulan data awal mulai dilaksanakan pada Mei 2018 sampai pada Juli 2019. Jenis data yang digunakan pada penelitian ini terdiri dari data primer yaitu data utama berupa hasil dari observasi dan wawancara dengan informan dan data sekunder berupa data pendukung atau pelengkap yang berkaitan dengan penelitian ini. Teknik pengumpulan data yang dilakukan oleh peneliti ialah menggunakan tiga metode yaitu wawancara dengan informan, observasi di lapangan, dan studi dokumentasi. Dalam menguji keabsahan data, peneliti memakai teknik triangulasi sumber yang digunakan dengan cara membandingkan data yang diperoleh dalam penelitian.

\section{Hasil dan Pembahasan}

Pada penelitian ini, peneliti menggunakan teori analisis SWOT yang dikemukakan oleh Salusu (2015) untuk menganalisis kekuatan, kelemahan, peluang, dan ancaman pada kapabilitas BPBD Kota Padang dalam pengurangan risiko bencana di Kota Padang. Adapun indikator yang telah dianalisis peneliti dapat diuraikan sebagai berikut:

\section{Strengths (Kekuatan)}

Menurut Salusu (2015) kekuatan ialah keadaan dan kecakapan internal yang bersifat positif yang membolehkan organisasi mempunyai keuntungan stratejik dalam menggapai sasarannya. Berdasarkan penelitian yang dilakukan di lapangan dapat diketahui bahwa yang menjadi kekuatan pada kapabilitas BPBD Kota Padang ialah adanya aturan yang jelas yang dimiliki BPBD Kota Padang. Aturan-aturan tersebut berbentuk Peraturan Kepala BNPB, Rencana Penanggulangan Bencana, Peraturan Daerah, Peraturan Wali Kota, dan UndangUndang. Dengan adanya peraturan-peraturan tersebut tentunya dapat menjadi pedoman bagi BPBD Kota Padang dalam melaksanakan tugas dan fungsinya sehingga setiap program dan kegiatan yang dijalankan oleh BPBD Kota Padang memiliki dasar yang jelas.

Selanjutnya kekuatan yang dimiliki BPBD Kota Padang dapat dilihat dari adanya koordinasi yang dilakukan dengan para stakeholder yang terlibat dalam kebencanaan dalam bentuk roll call, coffee morning, dan kunjungan dengan seluruh stakeholder yang terlibat dalam penanggulangan bencana. Hal ini tentunya dapat menjadi keuntungan bagi BPBD Kota Padang dalam memudahkan tugasnya dalam melakukan penanggulangan bencana sehingga penangangan bencana dapat lebih efektif dan efisien.

\section{Weaknesses (Kelemahan)}

Salusu (2015) mengatakan bahwa kelemahan pada umumnya adalah kekurangan yang dipunyai oleh organisasi dibandingkan dengan organisasi yang lain. Berdasarkan hasil temuan di lapangan maka ditemukan yang menjadi kelemahan bagi kapabilitas BPBD Kota Padang dalam pengurangan risiko bencana di Kota Padang ialah jumlah sumber daya manusia yang masih belum mencukupi. Akibatnya BPBD Kota Padang menjadi kewalahan dalam melaksanakan tugas dan fungsinya dalam penanggulangan bencana. 
Jumlah tenaga yang dimiliki oleh BPBD Kota Padang masih jauh dari jumlah yang seharusnya sehingga BPBD Kota Padang menggunakan tenaga kontrak dan tenaga relawan agar dapat mengkoordinir seluruh bidang di BPBD Kota Padang. Kekurangan jumlah sumber daya manusia yang dimiliki oleh BPBD Kota Padang dikarenakan anggaran yang minim untuk kebencanaan sehingga jumlah pegawai yang akan direkrut menjadi terbatas.

Kemudian tingkat mutasi yang tinggi juga menjadi kelemahan bagi BPBD Kota Padang. Hal ini menyebabkan saat terjadi mutasi, pegawai baru yang menggantikan suatu posisi di BPBD Kota Padang harus memulai dari nol lagi dalam memahami tugas dan fungsinya sebagai pegawai BPBD.

Selain itu, sarana dan prasarana yang dimiliki BPBD Kota Padang saat ini masih belum memenuhi dari segi jumlah dan kelengkapan. Kekurangan peralatan yang dimiliki BPBD Kota Padang disebabkan oleh sulitnya pengadaan barang yang juga dikarenakan anggaran yang minim yang dimiliki BPBD Kota Padang dan barang yang memang sudah tidak layak pakai. Hal ini tentunya dapat menghambat BPBD Kota Padang dalam melaksanakan tugas dalam penanggulangan bencana.

Yang terakhir ialah anggaran yang masih sangat terbatas. Ketidakseriusan pemerintah dalam melihat isu kebencanaan sebagai isu strategis juga berpengaruh terhadap anggaran yang dianggarkan pemerintah untuk kebencanaan termasuk anggaran BPBD Kota Padang. Anggaran yang minim tentu menghambat pelaksanaan kegiatan BPBD Kota Padang dalam pengurangan risiko bencana di Kota Padang sehingga BPBD Kota Padang harus bijak dalam memprioritaskan kegiatan yang memiliki urgensi paling tinggi.

\section{Opportunities (Peluang)}

Menurut Salusu (2015) menyatakan bahwa peluang dapat diterjemahkan sebagai kesempatan dan kemungkinan yang tersaji dan bisa digunakan untuk menggerakkan proses kinerja pembangunan daerah atau organisasi yang bersangkutan. Dari hasil yang peniliti dapatkan di lapangan, ditemukan yang menjadi peluang bagi kapabilitas BPBD Kota Padang dalam pengurangan risiko bencana di Kota Padang ialah peran aktif dari organisasi-organisasi terkait kebencanaan yang dapat membantu pelaksanaan tugas BPBD Kota Padang dalam pengurangan risiko bencana. Dalam melaksanakan tugasnya di lapangan, BPBD Kota Padang banyak dibantu oleh organisasi yang terlibat dalam kebencanaan seperti KSB (Kelompok Siaga Bencana). Hal ini dapat membantu BPBD Kota Padang yang saat ini masih terkendala karena keterbatasan anggaran dan tenaga personel.

Kemudian LSM (Lembaga Swadaya Masyarakat) yang ada di Kota Padang juga sudah aktif berpartisipasi, contohnya saja dalam pembuatan Rencana Kontijensi dan melihat kekurangan yang ada di BPBD Kota Padang serta memberikan masukan-masukan kepada BPBD Kota Padang. Hal ini tentu sangat membantu BPBD Kota Padang terutama saat BPBD Kota Padang masih belum memiliki kapasitas yang mencukupi dalam suatu aspek, maka LSM dapat menutupi aspek tersebut dengan kapasitas mereka.

Selain itu, adanya aturan yang mendukung penganggaran BPBD Kota Padang dalam bentuk SPM (Standar Pelayanan Minimal) yang juga sedang dalam proses untuk disahkan sehingga nantinya akan ada slot anggaran yang dapat digunakan untuk menunjang kinerja BPBD Kota Padang dalam penanggulangan bencana.

\section{Threats (Ancaman)}

Salusu (2015) mengatakan bahwa ancaman memiliki arti sebagai suatu keadaan atau persoalan yang datang dari luar dan bisa menyebabkan kesulitan, kendala atau tantangan yang vital bagi suatu daerah atau institusi tertentu. 
Berdasarkan penelitian yang ditemukan oleh peneliti dapat diketahui bahwa yang menjadi ancaman bagi kapabilitas BPBD Kota Padang adalah Kota Padang memiliki tingkat ancaman terhadap bencana yang cukup besar seperti gempa dan tsunami yang dapat menimbulkan kerusakan dan bahkan korban jiwa sehingga mengancam BPBD Kota Padang dalam menjalankan tugasnya.

Selanjutnya, masih kurangnya kapasitas dan pemahaman masyarakat terhadap penanggulangan bencana menjadi ancaman bagi BPBD Kota Padang dalam upaya pengurangan risiko bencana. Masyarakat masih sulit untuk dapat mempercayai hasil penelitian yang dilakukan oleh para ahli dan menganggap bencana sebagai act of god.

\section{Penutup}

Dari segi kekuatan, kelemahan, peluang, dan ancaman pada kapabilitas BPBD Kota Padang dalam pengurangan risiko bencana di Kota Padang maka dapat disimpulkan bahwa yang menjadi kekuatan bagi kapabilitas BPBD Kota Padang dalam pengurangan risiko bencana di Kota Padang ialah adanya aturan yang jelas dan adanya koordinasi yang dilakukan dengan para stakeholder yang terlibat dalam kebencanaan. Dengan memanfaatkan kekuatan-kekuatan tersebut diharapkan BPBD Kota Padang dapat lebih efektif dan efisien dalam melakukan pengurangan risiko bencana.

Kemudian yang menjadi kelemahannya ialah jumlah sumber daya manusia yang masih belum mencukupi, tingkat mutasi yang tinggi, jumlah sarana dan prasarana yang dipunyai saat ini masih belum mencukupi serta anggaran yang masih terbatas. Dengan kelemahan yang dimiliki saat ini diharapkan BPBD Kota Padang dapat berbenah dan memperbaiki aspekaspek yang menjadi kelemahan tersebut.

Selanjutnya yang menjadi peluang bagi kapabilitas BPBD Kota Padang ialah peran aktif dari organisasi-organisasi terkait kebencanaan dan adanya aturan yang sedang dibuat dalam mendukung penganggaran BPBD Kota Padang. BPBD Kota Padang diharapkan dapat memanfaatkan peluang yang ada tersebut sehingga pelaksanaan penanggulangan bencana oleh BPBD Kota Padang dapat lebih meningkat kualitasnya.

Selain itu, yang menjadi ancaman bagi kapabilitas BPBD Kota Padang ialah Kota Padang memiliki tingkat ancaman terhadap bencana yang cukup besar dan masih kurangnya kapasitas dan pemahaman masyarakat terhadap penanggulangan bencana. Harapannya BPBD dapat merumuskan strategi-strategi yang tepat dalam menghadapi ancaman yang ada.

\section{Daftar Pustaka}

Dokumen RPB Kota Padang 2014 - 2019

John Twigg. (2009). Karakterisrik Masyarakat Tahan Bencana: sebuah catatan panduan. Oxfam.

Jonatan Lassa, dkk. (2009). Kiat Tepat Mengurangi Risiko Bencana: Pengelolaan Risiko Bencana Berbasis Komunitas (PRBBK). Jakarta. PT Gramedia Widiasarana Indonesia

Kusumasari, Bevaola. (2014). Manajemen Bencana dan Kapabilitas Pemerintah Lokal. Yogyakarta: Penerbit Gava Media.

Moleong, Lexy J. (2009). Metode Penelitian Kualitatif (Edisi Revisi). Bandung: PT Remaja Rosdakarya.

Meiwanda, G. (2016). Kapabilitas Pemerintah Daerah Provinsi Riau: Hambatan dan Tantangan Pengendalian Kebakaran. Jurnal Ilmu Sosial dan Ilmu Politik, 10(3)

Nurjanah, dkk. 2013. Manajemen Bencana. Bandung: Alfabeta.

Peraturan Walikota Padang Nomor 95 Tahun 2016 Tentang Kedudukan, Susunan Organisasi,

Jurnal Perspektif: Jurnal Kajian Sosiologi dan Pendidikan Vol. 2, No. 3, Th. 2019 ISSN. 2622-1748 
Eko Sammara Valentino Turnip, Zikri Alhadi Analisis SWOT Terhadap Kapabilitas BPBD Kota Padang dalam Pengurangan Risiko Bencana di Kota Padang

Laporan Hasil Analisa Jabatan, Analisa Beban Kerja dan Standar Kompetensi Jabatan Badan Penanggulangan Bencana Daerah Kota Padang Tahun 2018

Salusu. (2015). Pengambilan Keputusan Strategik Untuk Organisasi Publik dan Organisasi NonProfit. Jakarta: Grasindo

Sugiyono (2012). Metode Penelitian Kuantitatif dan Kualitatif R\&D. Bandung: Alfabeta Undang-Undang Nomor 24 Tahun 2007 Tentang Penanggulangan Bencana.

Yana Safitri, Santoso Tri Raharjo, Rudi Saparudin Darwis. (2017). Meningkatkan Kapabilitas Pekerja Sosial Melalui Supervisi Pekerjaan Sosial. Jurnal Penelitian \& PKM ,4(2) 